https://helda.helsinki.fi

\title{
Conversation analysis and psychotherapeutic change
}

\section{Voutilainen, Liisa}

Palgrave Macmillan

2018

Voutilainen , L , Rossano , F \& Peräkylä , A 2018 , Conversation analysis and psychotherapeutic change . in S Pekarek Doehler, J Wagner \& E González-Martiínez (eds) , Longitudinal Studies on the Organization of Social Interaction . Palgrave Macmillan, London , pp. 225-254 . https://doi.org/10.1057/978-1-137-57007-9_8

http://hdl.handle.net/10138/310588

https://doi.org/10.1057/978-1-137-57007-9_8

unspecified

acceptedVersion

Downloaded from Helda, University of Helsinki institutional repository.

This is an electronic reprint of the original article.

This reprint may differ from the original in pagination and typographic detail.

Please cite the original version. 
Liisa Voutilainen, Federico Rossano and Anssi Peräkylä

\section{Conversation analysis and psychotherapeutic change}

\section{Introduction}

Psychotherapy, even in its short-term forms, is a longitudinal process, involving several recurrent meetings between the therapist and the client or clients. The participants orient themselves to this continuous nature of therapy. Unlike much ordinary conversation, and many forms of institutional interaction, in psychotherapy the topics do not need to be closed or resolved during single encounters. In most cases, the discussion on any given topic can be taken up at a later point in time.

Psychotherapy is geared to facilitate change. The recurrent encounters between therapists and clients aim at improving the clients' psychological functioning and health. In general terms, starting from the classical psychoanalytical tradition, and continuing to the current integrative models, a common aim in many types of psychotherapy is to increase the clients' contact with their problematic emotional experiences and parts of the self, and increase their self-reflexive abilities (Norcross and Goldried, 2005; Fonagy et al., 2002). One well-known method to describe this kind of psychotherapeutic change, applicable to any type of psychotherapy, is the assimilation model of a problematic experience (Stiles et al, 1990; Stiles, 2002). In this model, a therapeutic change is documented using transcripts of a series of therapy sessions. Investigation of client's talk on a particular topic seeks to explicate a process in which previously avoided experience becomes integrated to the client's self. The aim of this chapter is to discuss ways in which conversation analysis (CA) can be applied to address such emerging change process. Unlike assimilation model, our CA-based depiction of change is sensitive to the sequential contexts of the talk about problematic experiences.

Following the lead of researchers of learning in interaction (e.g. Mondada and Pekarek Doehler, 2004; Martin, 2004; Melander and Sahlström, 2009), CA of psychotherapy has begun to track 
longitudinal processes in psychotherapy (Voutilainen, Peräkylä and Ruusuvuori., 2011; Peräkylä 2011, 2012; Bercelli, Rossano and Viaro, 2013; Muntigl 2013). In the current chapter, based on the authors' empirical CA work on cognitive therapy, systemic therapy and psychoanalysis, we will discuss how the participants of a psychotherapy orient to the longitudinal nature of their interaction, and how the emergence of change can be documented from the unfolding of the interaction itself. In particular, the aim of the chapter is to discuss relations between development of a theme and sequential context over time.

The authors' earlier research is based on large data corpuses of cognitive therapy, systemic therapy and psychoanalysis in Finland and Italy (Voutilainen, Peräkylä and Ruusuvuori, 2011; Bercelli, Rossano and Viaro, 2013; Peräkylä 2011; 2012). In this chapter, we will discuss three individual therapies, one from each therapy type. The data from cognitive therapy consist of audio recordings of 57 weekly sessions from the beginning phase of a therapy until the last session of this therapy, from systemic therapy 14 consecutive sessions from the beginning phase of the therapy, and from psychoanalysis 20 subsequent sessions from the middle phase of a therapy.

We will focus on a central theme of discussion in each therapy, and illustrate the development of three themes: 1) client's negative feelings towards her mother 2) client's dominant behaviour towards her husband, and 3) client's disappointment at his father. These themes were selected because they were, to our interpretation of the members' orientations, important in the particular therapies. Each theme manifested itself in a prominent way in the dialogue between the client and the therapist, and was connected to what seemed to be central in the client's problematic experiences. In Schegloff's (2007) terms, they were thematic threads that run across sequences and encounters.

Our analysis will link the development of these themes to particular two-part sequences. Our point of departure is a concrete sequence in each therapy where central content regarding the theme is articulated in a prominent and explicit way. The first turn in these two-part sequences is the therapist's intervention, which clearly explicates this central content, and invites the client to reflect on it. We call the sequences at hand "focal sequences" As conversational actions, the therapist's first turns are 
versions of the type of intervention that Bercelli et al. (2008) have called reinterpretations (cf. interpretations in Vehviläinen, 2003; Peräkylä, 2004). Compared to another prevalent psychotherapeutic intervention - formulation - that suggests a meaning of what the client has said in the prior turn or turns, (re)interpretations do more: they convey the therapist's own view about the patient's mind or circumstances. (Peräkylä, 2005; Bercelli, Rossano and Viaro., 2008). These types of interventions make a strong relevance for a response that elaborates the content that was offered by the therapist (Peräkylä, 2005; Bercelli, Rossano and Viaro, 2008).

We will discuss the relation between themes and sequences in three ways. First, we will show a longitudinal change in the ways in which a theme is addressed in a recurrent sequence type. Second, we will show how the content that is explicated in the reinterpretation is present in other kinds of sequences in earlier sessions. Third, we will consider the further development and sequential context of a theme in sessions that follow a (re)interpretation. Altogether, our aim is to show how the microscopic analysis of sequences and the more macroscopic analysis of themes complement each other in research on therapeutic change.

\section{Change in a focal sequence}

The focal sequence we will discuss in this section reoccurred in the (cognitive) therapy in question. In these sequences, the therapist directly suggested to the client a more explicit expression of negative feelings towards her mother, instead of self-blame. These interventions do not recur in exactly similar form, but in a broad sense their content is the same ("the original object of anger is the mother, not the client's self") and they can be seen to represent sequentially a similar type of action: they present the therapist's view, based on what the client has said, and that they invite an elaborated response.

During the therapy, the client's responses to the therapist's focal interventions were recast: from rejection through ambivalence to agreement (Voutilainen, Peräkylä and Ruusuvuori, 2011). The first excerpt shows how the client clearly resists the therapist's suggestion in the early phase of the therapy. Prior to the excerpt, the client expressed indirectly, through a story, that negative feelings 
towards her mother. In the focal intervention in the beginning of the excerpt, the therapist explicates these feelings.

Ex. (1)

01 T: No ei oo ihme et sust tuntuu et (.) hylätyltä

It's no wonder that you feel (.) rejected

02 ja.hhhh (1.3) ${ }^{\circ}$ semmoselta et kukaan ei vä000litä․

and .hhh (1.3) ${ }^{\circ}$ like no one $\mathrm{ca}^{000} \mathrm{res}^{\circ 0}$.

$03(4.0)$

04 ?: .hff

$05 \quad(2.3)$

$06 \mathrm{~T}:$ Kұ̣llä tost $\uparrow$ varmaan semmone tunne tulee ${ }^{\circ} \mathrm{ki}$ että ${ }^{\circ}$.

I $\uparrow$ guess that does make one feel $l i^{\circ}$ ke that ${ }^{\circ}$. 
08 C: .hfhhhh kryhh-kryhmm hmhhhhhhh >Sit ku mä oon .hfhhhh kryhh-kryhmm hmhhhhhhh >Then it's that I

09 aina sitä niinku< (0.3) >m-'t jos mä \#Villelle \#have always like< (0.3) $>b^{\prime} t$ if I speak \#to Ville\#

10 noista puhun et se rupee sitä sitte .hh (0.4)

about those then he starts to .hh (0.4)

11 sättimää n tai haukkumaan tai (1.5) puhumaan rail her or berate or (1.5) say bad things about

12 siitä pahaa mää sit hirvees $\uparrow t i$ puolustelen sitä her and then I deathly defend her and .hfff (.) so that no one is like (0.5) allowed 
In her statement It's no wonder that you feel rejected and like no one cares (lines 1-2) and further in the expansion of that statement I guess that does make one feel like that (line 6), the therapist describes the client's mental state in affective terms that explicate negative feelings that the client expressed indirectly through a story. The turn design foregrounds the therapist's own voice, or a voice of "anyone's reasoning", through the prefaces "it's no wonder that" and "I guess that". In this way, the therapist offers this content as a suggestion to the client to elaborate on, preferably to agree with. However, the client resists this. She does not respond to it in any way during 12 seconds of silence. After the silence, the client starts to describe how she reacts defensively when her spouse talks negatively about the client's mother. By giving this account, in the sequential context after the therapist's suggestion, the client not only resists the therapist's reinterpretation but also backs off from the negative emotion that she indirectly expressed through her earlier storytelling. It should be noted that the client does not resist the therapeutic agenda as such, as she continues with a reflection of her reactions towards the content of the therapist's turn.

The following excerpt shows another instance of this sequence type, some months later. In the reinterpretation, the therapist draws attention to the client's negative emotions towards mother (and here also to father) and questions the client's image of herself as faulty. Due to space limitations, we show only the latter part of the intervention. Prior to the excerpt, the participants have talked about the client's lack of security in her childhood. The therapist has again drawn attention to the conduct of the client's mother, and started to challenge the client's self-blame just prior to the excerpt.

Ex. (2) 
So has it been your fault originally or.=

$02 \mathrm{C}: \quad=>\mathrm{Ni}$ =ttä toisin sanoen että olen< (.) olen

=>you meanso that in other words that I am< (.) I am

am disappointed at my parfentsf kind of.so like that.

$\downarrow$ Yeah. $=$

$06 \mathrm{C}: \quad=\mathrm{Nii}$.

=Yeah .

07

$(0.5)$

$08 \mathrm{~T}$ : Ne on ollu semmosii ku $\uparrow$ ne $\uparrow$ on $\uparrow$ ollu.= 
$09 \mathrm{C}$

10

$11 \mathrm{~T}:$

12

13

$14 \mathrm{C}$

15

$16 \mathrm{C}:$
$=\mathrm{Ni}$.

$=$ Yeah

$(1.4)$

Mutta sä oot alkanu luulee et

But you have started to think that you are

sus on joku vika.

somewhow faulty.

$(2.0)$

$\mathrm{N}-\mathrm{ni}$.

Y-yeah

$(5.8)$

Mmm but as the problem is that I still don't want to and

pysty (1.0) pysty syyttämään (1.2) 
to and somehow I'm not able to (1.0) able to accuse (1.2)

tai olemaan pettyny niinku vanhempiin (.) no

or to be disappointed with my parents (.) well

isään kyllä mutta tota en äitooin ${ }^{\circ}$.

with father yes but erm not with mot $^{\circ}{ }^{\circ}$ her ${ }^{\circ}$.

$21 \mathrm{P}:=$ = $=$ En $[\mathrm{mä}$ tiiä.

$\uparrow I$ [dont know.

In line 2 the client responds to the therapist's suggestion by formulating her understanding of what the therapist's previous talk means, that the client is disappointed at her parents. This refers to what the therapist had suggested some minutes earlier: the client might try to consciously convert her thinking in the case of self-blame in relation to a person to thinking that she is disappointed at that very person. The client displays that she formulates the therapist's understanding (not necessarily her own) as she prefaces her turn with You mean/So in other words (Nii että toisin sanoen, in the original data). This can be heard as an ironic repair initiation, referring to the earlier suggestion. Despite this, by showing that she understands what the therapist means (lines 2-3) and by then accepting her reasoning (line 6), the client, unlike in the previous excerpt, shows alignment with the therapist's first turn. Thus, the client's resistance towards the content that the therapist suggests is less straightforward than earlier. In lines 8 and $11-12$, the therapist explicates the reinterpretation that she has been suggesting. The 
therapist points out that the client's parents have been what they have been (line 8), which is confirmed by the client (line 9). The therapist's next turn, in which she suggests that the client has started to think that she is somehow faulty (lines 11-12) gets a delayed and disfluent (albeit agreeing) response (line 14). In lines 16-19, the client eventually backs off from the reinterpretation.

This excerpt is a typical example of the client's response to these kinds of reinterpretations during the therapy: the client first agrees with the therapist but then withdraws. Importantly, the client does not resist the sequential implication of the reinterpretation as such, but gives an elaborated response. She also displays understanding of the direction to which the therapeutic work should go by stating I still don't want to and I'm not able (lines 16-17), and expressing ambivalence I don't know (line 21).

The next excerpt shows an instance towards the end phase of the therapy with a further change in the client's response. The therapist again points out that the client's mother's behaviour is not something that the client should blame herself for. The client now displays extended agreement with the conclusion. Due to space limitations, the excerpt shows only the end of the therapist's longer reinterpretation and the beginning of the client's longer response.

Ex. (3)

$01 \mathrm{~T}$ : =Jos hän sattuu olee semmonen ihminen.

=If she happens to be that kind of person.

$02 \quad($.

03 P: Nii:. 
Yeah: .

$04 \quad(0.6)$

05 P: Niinhän se on hheh heh (.) .hhhhh £niinhän se That's the way it is indeed heh (.). hhhhh

06 on£=EIKU en mä koskaan niinku (.)

fthat's the way it isf I MEAN I have never (.)

07 en mä voi .hhhhh \#e:\# (.) m-m ku en mä (.)

I can't .hhhh \#e:\# (.) m-m as I don't (.)

08 niinku ymmärrä että m- (.) \#mmmmm\# et jos mä

understand wh-(.) \#mmmm\# if I tried to

09 lähtisin niinku itestäni ettimään (.) jotakin

find something from myself (.) like I don't know

10 kun en mä niinku tiedä mitä se vois olla .hh[hhh

what that would be .hhh[hh As I nevertheless 


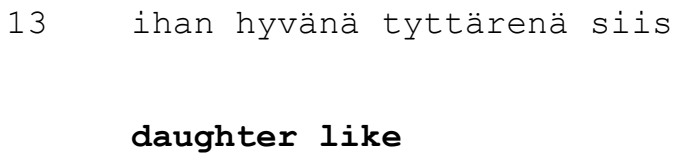

The client starts to confirm the therapist's reinterpretation already when the therapist's turn is in progress (not shown in the excerpt) and then in line 3, and subsequently in line 5 , displays strong agreement through the repeated phrase that's the way it is. Thereafter the client points out that her own observations support this: she cannot find the fault in herself (lines 7-10). After what is shown in the excerpt, the client goes on to display further evidence that support the therapist's suggestion. Now, unlike in the earlier rounds, the client treats this case as closed and unproblematic: she can agree with the suggestion, based on her independent reasoning.

The three excerpts above illustrate how a longitudinal change in psychotherapy can be documented from a recurring type of sequence. In this case, the long-term change shows in the client's responses, as her responses to the therapist's reinterpretation evolve. By looking at the client's talk in a similar sequential context over time (in responses to reinterpretations), it was possible to see a robust change, although in other sequential contexts the ways in which the client related to this topic varied (Voutilainen, Peräkylä and Ruusuvuori, 2011).

In the next sections we will look at how a particular theme becomes discussed in other kinds of sequential contexts before and after the point in time when the focal reinterpretation is delivered. 


\section{Sequences leading to a focal intervention}

What we call a "focal sequence" is not the first context in which the topic of the focal intervention is introduced. In this section, we will show that before the therapist explicates the content in the reinterpretation, the theme is discussed in other types of sequences. Often focal sequences are the result of a long work of questioning, highlighting similarities across situations and connecting threads, rather than a therapist immediate response to something occurring in that session. As such, opportunities to unpack a reinterpretation can be passed on to later sessions so that separate threads can be tied up and a reinterpretation unfold more effectively.

To gather information, therapists can start multiple enquiry sequences (Bercelli, Rossano and Viaro, 2008; 2013), via open-ended questions or other actions eliciting clients' extended (multi-unit) tellings about their own events and experiences. Enquiry sequences can be followed by the therapist's reinterpretations. However, therapists can start different lines of enquiry one after the other without having to provide any reinterpretation. Nonetheless, at some point of the therapy, the therapist usually provides a reinterpretation. Accordingly, courses of action concerning different topics can emerge and develop somehow "in parallel" throughout the therapy: one can start a new topic while a previously started one is far from complete. In what follows we show data from a systemic therapy in which a therapist prepares the material for his reinterpretation across multiple sessions.

In the earliest sessions of the therapy, the client has complained about the status of her marital relationship and manifested the desire of ending her marriage. The therapist work aims at highlighting the client's dominant behaviour towards her husband. In what follows we trace two central topics, or threads of talk (Schegloff, 2007) - two lines of enquiry in this case - which link distantly placed enquiry sequences to the key reinterpretative point (our "focal intervention" here) that the patient is "so dominant" towards her husband (excerpt 6, lines 3-4). 


\section{First thread}

The first thread starts in the $4^{\text {th }}$ session, within an enquiry sequence in which the therapist has asked the client to describe how her own mother would characterize the personality of her children. The client says that her mother would say that her brother is too nice, too good-natured and the sequence is further expanded with more talk about her brother. In a further expansion of this sequence (excerpt 4 below) the participants agree on a point that will be key for the reinterpretation that will be delivered three sessions later.

Ex. (4)

$01 \mathrm{C}$

quindi ecco lei fa queste cose molto:(1.2)

so well she ((the client's sister-in-law)) does these very: (1.2)

plateali e: alla fine mio fratello sembra (.)

blatant things an:d at the end my brother seems (.)

come dominante alme nno da casa sula

as dominant according at [least to your fami[1y's view

$06 \mathrm{C}$ :

[si

[sì

[yes

[yes

$07 \mathrm{~T}$ :

è lei $\downarrow=$

it's her $\downarrow=$ 


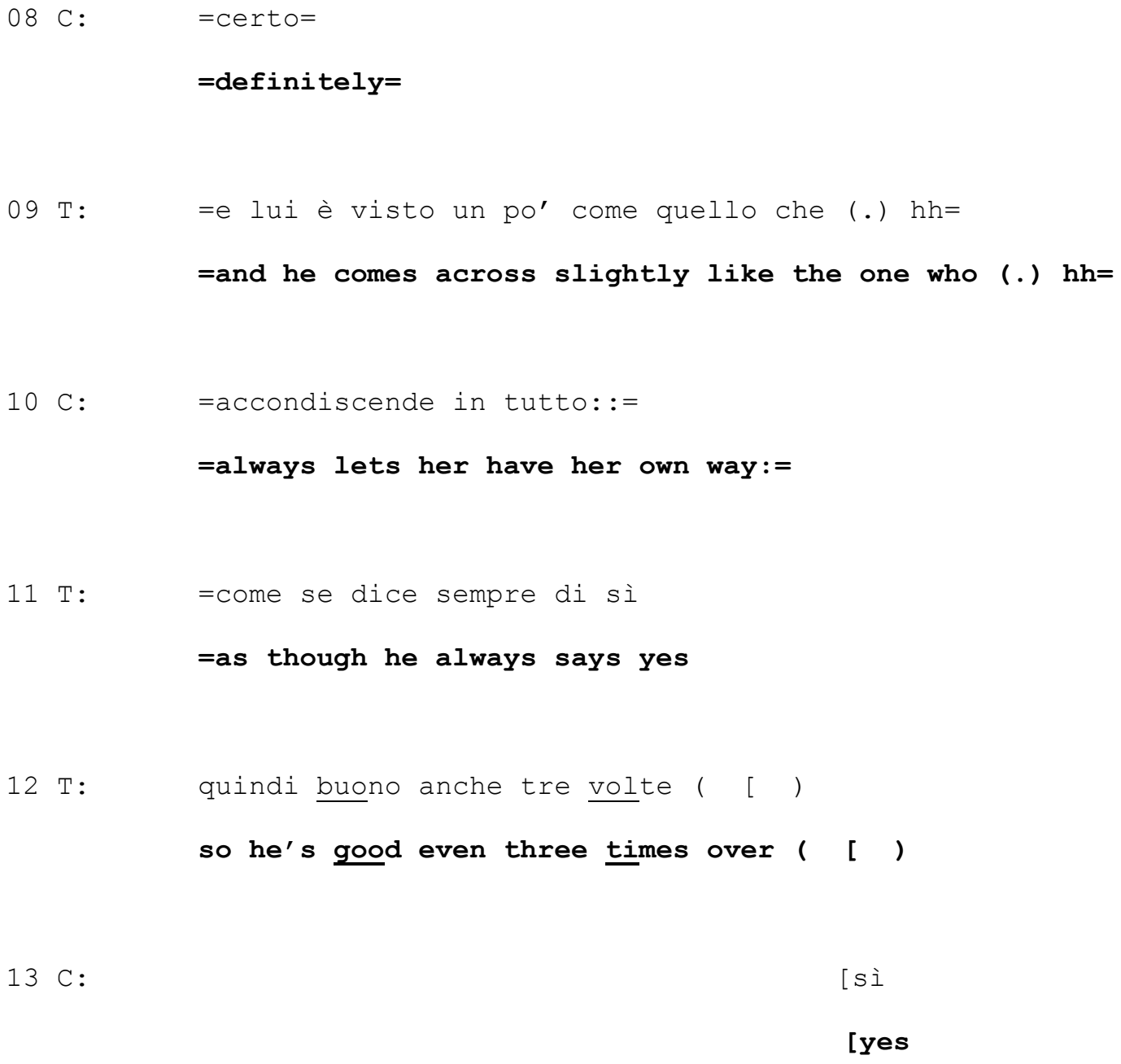

In excerpt 4, the therapist characterizes the client's sister-in-law as acting "dominant" over her husband (lines 4-7), who is instead depicted as "good even three times over" (line 12). The therapist does so through a series of formulations (lines $4-5,9,11-12$ ) in which he explicitly says that the fact that her brother comes across as too nice and in a sense weak is the result of his wife acting so dominant towards him.

This point, discussed in the $4^{\text {th }}$ session, is resumed in the $7^{\text {th }}$ one, as shown in excerpt 5 below. At lines 1-3 the client is talking about her husband. At lines 4-10 the therapist resumes the point discussed three sessions earlier (about her brother being good "three times over"). Through this resumption he starts a new enquiry sequence that prepares the reinterpretation including "so dominant" (excerpt 6). 
Ex. (5)

$01 \mathrm{C}: \quad$ perché Giulio è quello che non-

because Giulio ((client's husband)) is the one who never-

02

non dice mai di no, $(0.5)$ è buono (0.3) però poi magari

ever says no, (0.5) he's a good person (0.3) but then perhaps

03

non: (.) non ottempera ai=

he doesn:'t (.) doesn't come up with the=

$04 \mathrm{~T}: \quad$ =per quante volte?

how much? ((literally from the Italian: how many times?))

05

$(0.4)$

$06 \mathrm{C}: \quad$ che cosa?

what?

$07 \mathrm{~T}: \quad{ }^{\circ}$ quante volte è buono ${ }^{\circ}$

${ }^{\circ}$ how good is he ${ }^{\circ}$ ((literally: how many times is he good))

09 T: suo fratello ha detto che è tre volte buono no? (.)

your brother you said he's good three times over right? (.)

with his wife 

fhm but diffferently: ( (smile voice)) yes, and this:=

At line 2 the client says that her husband is "a good person", using the same term ("good") she had used for her brother three sessions earlier. The therapist interrupts the client by asking "how much?" that can be heard as referring both to the term "good" used by the client and to the therapist's formulation ("good even three times over") he had used three sessions earlier. The client initially doesn't seem to understand (see the repair initiation at line 6) until she answers, at line 12, that her husband is even "much more" (good) than her brother. By resuming past talk the therapist here opens 
a further line of enquiry by asking the client to provide her views on her own marital relationship, now compared to her brother's one. At lines 19-21 the therapist then formulates the client's answer in terms of marital relationships and dominance, as he had done three sessions earlier while talking about the client's brother: the therapist proposes that the client is even more dominant over her own husband than her sister-in-law is over her brother.

The term "dominant" is used again in the reinterpretation that constitutes the focal sequence here. It occurs one minute after excerpt 5. Given the temporal proximity, "so dominant" (line 4 in excerpt 6) is hearable as both resuming the formulation produced in excerpt 5 and being grounded in it. It does so by mirroring the previous "even... more dominant" (line 20 in excerpt 5).

Ex. (6)

$01 \mathrm{~T}$ : avevo pensato che fosse anche una- (0.3) hh così (.) una cosa I was thinking it was also a- (0.3) hh like (.) something that che mi era venuta in mente (0.5) hh proprio (0.4) rivedendo un occurred to me $(0.5)$ hh precisely (0.4) as I was reconsidering po' insomma questo rapporto dove a volte l'essere (0.8) hh (.) somewhat this relationship in which at times being $(0.8) \mathrm{hh}($. 
We have thus reconstructed one thread leading from a series of enquiry sequences, across two different sessions, to the target element of the focal sequence: "so dominant".

\section{Second thread}

The second thread starts also in the $4^{\text {th }}$ session, precisely when the client answers a therapist's question concerning her father's views about his children. This enquiry sequence follows one regarding her mother's views on the same subject, and the two sequences are manifestly connected one to the other as related items in the therapist's enquiring agenda. While telling a story relevant to the therapist's question, the client produces a slip of the tongue, shown in excerpt 7 below.

Ex. (7)

$01 \mathrm{C}: \quad[\ldots]$ qualche giorno fa che ero a Cuneo, è venuto fuori- mio [...] a few days ago I was in Cuneo, it came out- my padre (.) Eha fatto£ delle battute, (.) e- ed eravamo tutti e tre father (.) fhe wasf wisecracking, (.) and- and the three of us 
$05 \mathrm{~T}: \quad$ =la moglie di suo marito

=your husband's wife

[hm

$09 \mathrm{~T}$

${ }^{\circ}$ di suo fratello

'your brother's wife

10

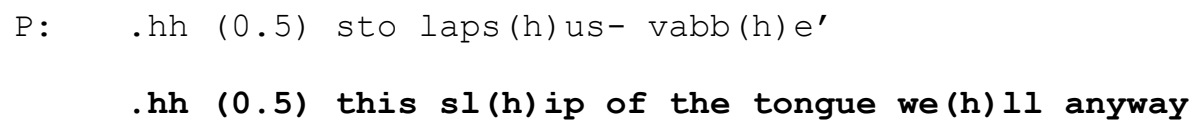

\section{((continues))}

The slip of the tongue occurs at lines 3-4 ("my husband's wife"), at line 5 the therapist mentions it and at line 7 the client repairs it. The therapist produces no comment nor enquires any further after the client's repair. 
Three sessions later, in the $7^{\text {th }}$ session, the therapist recalls this slip of the tongue and asks a question about it, as shown in excerpt 8 below (which is the continuation of excerpt 5). At lines 28-29 the therapist asks the client to interpret that slip of the tongue. At line 34 the client begins answering the question. This enquiry sequence leads directly to the focal sequence targeted by our analysis.

Ex. (8)

24 T: una volta li ha anche confusi, se lo ricorda no?

you once got them mixed up too, you remember don't you?

$25 \mathrm{C}: \quad$ hh $\mathrm{sì}=$

hh yes $=$

$26 \mathrm{~T}: \quad=e c c 0$.

=right.

27

$(1.8)$

$28 \mathrm{~T}$ : e io mi sono domandato che cosa voleva dire, lei se-

and I was wondering what you meant, and did- did you

29

anche se l'è domandato che- [che cosa- secondo lei

also wonder what- [what- according to you

$30 \mathrm{C}$ :

[sì

[yes

$31 \mathrm{~T}:$

che cosa voleva dire? (.) perché li ha confusi? 


$$
\text { what did you really mean? (.) why did you mix them up? }
$$

$32 \mathrm{C}:$

mio fratello e mio marito?

my brother and my husband?

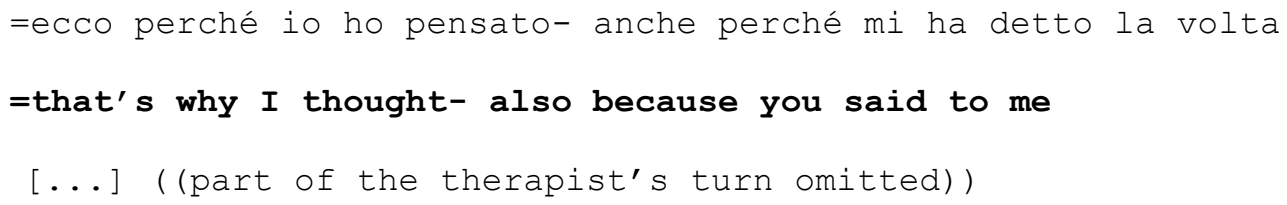

At line 24 the therapist recalls client's slip of the tongue, then at lines $28-31$ asks her to account for it. The client answers and offers her explanation (lines 34-36). Immediately after it, at line 37, the therapist starts a reinterpretative comment that is explicitly grounded in what the client has just said. This is the beginning of the reinterpretation containing "so dominant" (excerpt 6 above). The link between the client's explanation and the therapist's reinterpretation is rather transparent: if the client has directed her marital affairs (lines 35-36), then it can be inferred that she is "so dominant" towards her husband. This is then another line of enquiry leading to "so dominant", again across the $4^{\text {th }}$ and $7^{\text {th }}$ sessions. 
In attempting to build a unitary course of action and connecting different conversational threads, the therapist is faced with the problem of making the client see that these different conversational blocks are tied to one another. Moreover, the client's recollection of the previous threads becomes key for connecting the threads. According to Sacks (1992), a speaker can tie an utterance to previous talk through various tying techniques. In the systemic data, participants resume past talk in two main ways: through a dedicated pre-sequence and/or in an embedded way.

In excerpt 8 , at line 24 "you once got them mixed up too" explicitly refers to something that was said in a past occasion (the client's slip of the tongue which occurred three sessions earlier). Moreover, the therapist asks the client whether she remembers it.

Past talk can also be resumed in an embedded manner, by repeating parts of the talk to be resumed, rather than through a dedicated sequence. Note that repeating here is not merely telling previously told words and phrases, which could occur "by coincidence", but bringing off that such telling is "doing a 'repetition"” (Sacks, 1992, vol. I, p. 723, cf. the client's reuse of the therapist's idiomatic expression in cognitive therapy).

The two ways of resuming past talk - through a dedicated sequence and in an embedded manner - occur in combination in excerpt 5 . At line 4 the therapist interrupts the client's telling with a question that embeds a reference, through partial repetition, to an exchange from an earlier session, where the client's brother had been labelled as "good even three times over" (at line 59 of excerpt 4). The words "volte" ("times") and "buono" ("good") in the question "quante volte è buono?" index the past description where the same two words occurred. By repeating, in a hearably abrupt way (lines 34), a phrase which is highly idiomatic and hearable as an extreme case formulation (Pomerantz, 1986), the therapist displays that he is doing repetition rather than merely saying again what he said in an earlier occasion. Also in this case, then, what is resumed is both a past topic and a past course of action.

Note that a speaker can succeed in resuming a distant piece of talk, by repeating parts of it, if the listener can locate the past occurrence which the speaker refers to. Metaphors, uncommon figures 
of speech and extreme case formulations (like "good three times over") are easier to recall than plain talk. Therefore, therapists may recur to such 'memorable' expressions in order to facilitate their subsequent possible resumption.

Unlike in the excerpts from cognitive therapy, the systemic therapist did not repeat the same reinterpretation in different sessions, but the reinterpretation that was delivered at one point in time was preceded by enquiry sequences that took place in different sessions. The way in which the theme develops in its way from enquiry sequences to the reinterpretation, involves movement towards explication of the content in question. The client first talked about a problematic theme (dominant tendencies towards a partner, partner's submissive kindness) with regard to other people before it was explored in terms of her own experience (excerpt 6). This development in the theme connects to change in sequential contexts: the content of the reinterpretation is approached through questions and formulations before it is directly suggested by the therapist.

\section{Modification of the theme after the focal sequence}

While the previous section showed how a (re)interpretation is grounded in actions and thematic threads running across several sessions, the section at hand will focus on cross-session consequences, or "further life", of a focal intervention. The data come from psychoanalysis. Like in the previous section, the intervention involves an interpretation by the therapist. In particular, we will be investigating the work that is done by a third position utterance: the therapists comment that comes after the client's response to an interpretation. We will be focusing on thematic threads and their transformations that run from the third position utterance and are taken up by the participants during the subsequent sessions. However, unlike in previous section, the continuity between utterances in different sessions remains implicit.

Earlier during this session, the client has talked about his athletics hobby as a teenager, and especially about his disappointment for the lack of encouragement by his mother concerning this hobby. In his long interpretation (only the latter part is shown here), the therapist suggests that the 
client's disappointment at his mother, in fact involves a 'deeper' disappointment for the fact that the mother was not father. The sense of this particular interpretation is embedded in the participants' shared knowledge about the client's biography: his father became an alcoholic and eventually left the family when the client was in his early teens (see Peräkylä, 2012). So, the therapist's interpretation suggests that the client did not in fact miss mother's encouragement, but what he missed was the father being there. When the excerpt begins, the therapist is about halfway in the interpretation.

Ex. (9)

01 T: ... > Mä luulen et sun on< v:aikea oikeestaan, ... >I think that it's actually< diff:cult for you,

07 T: mt että isä punuttu .mt that father wassn't there. 
09 T: .hh Ja se ilmenee tällä tavalla että .hhh (0.2) \#ä:\# sie. hh And it shows in this way that .hhh (0.2) \#er:\# you

10 kaipat nitä ominaisuuksia (0.8) joita miss the characteristics $(0.8)$ that

11 <isässä 이isi ollut>.

<the father would have had >.

$12 \quad(2.2)$

$13 \mathrm{~T}:$ Ja (.) oot (tyytymätön) äitiin nyt And (.) you are (dissatisfied) now with mother for

14 siitä (0.7) mt että >äidillä ei ollu< niitä the fact (0.7) tch that the >mother didn't have< those

15 ominaisuuksia.

characteristics.

$16 \quad(1.6)$

17 T: Että äiti ei ollu isä.

That mother wasn't father.

$18 \quad(3.5)$

19 T: \#Isän::\# (1.0) tehtävänäh'n (.) tavallisesti

\#It's the fa:ther's (1.0) duty (.) normally 
(1.0) \#( ) to e\#ncourage $(0.5)$ the son to o-

outdoor activities and sports.

$22(6.0)$

23 T: mt Metsälle ja,

tch To hunting expeditions and,

$24 \quad(1.5)$

25 T: urheilukentille ja niin edelleen.

to athletic fields and so on.

$26 \quad(18.5)$

27 C: .mthhhhff hhhmthh (1.0) mt hhhh .mthhhhff hhhmthh (1.0) tch hhhh

29 C: .mthh Niil:, (.) Tottahan se on (.) on tietysti, .mthh Yeah: :, (.) It is true (.) true of course,

30 = Isänhän siellä kentän laidalla >ois pitäny< ollia =It is father who >should have been< by the atheltic field. 
32 C: Hihkumassa.=>Eikö niin<.

Whooping. =>shouldn't he<.

$33 \mathrm{~T}: \mathrm{Niin}$.

Yeah.

$34 \quad(10.0)$

35 T: .hh Ja urheiluseuran\#: :\# johtokunnassa

.hh And in the steering committee of the athletic club

36 (1.0) tukemassa nuorten työtä.

(1.0) supporting the youngsters work.

$37 \quad(5.2)$

$38 \mathrm{C}$ : Nii:

Yeah:

$39 \quad(35.0)$

$40 \mathrm{C}:$. mthhh ${ }^{\circ}$ (Tyt-) niin,

.$^{\circ} \mathrm{mthhh}{ }^{\circ}$ (Wok-) yeah ${ }^{\circ}$

$41 \quad(4.2)$ 
tch So $\downarrow$ I: somehow $>I$ didn't< didn't didn't $>$ for example<

43

lapsenakaan .hhh ees olettanu että isä \#e: :

\#even as a child.hh I din't assume that father \#erm\#

44

$\circ$ isä tekis semmosta ${ }^{\circ}$.

${ }^{\circ}$ father would do something like that ${ }^{\circ}$.

$45 \quad(4.7)$

$46 \mathrm{C}$ : ${ }^{\circ}$ Voisko se olla (ihan) niin. ${ }^{\circ}$

${ }^{\circ}$ Could it be (even) like that. ${ }^{\circ}$

$47 \quad(4.0)$

$48 \mathrm{~T}:{ }^{\circ} \mathrm{Nin} .{ }^{\circ}$

$49 \quad(1.0)$

$50 \mathrm{~T}$ : Jos sinusta tuntuu ${ }^{\circ}$ siltä ${ }^{\circ}$.

If you feel like ${ }^{\circ}$ that $^{\circ}$.

While the client's response (lines 29-32) is apparently agreeing with and elaborating the interpretation, it fails to take up the original edge of the interpretation (displacement of disappointment from father to mother) elaborating instead on the interpretation as it was revised in the therapist's pursuits of answer (especially in in lines 19-25). In his third position utterance (lines 3536), the therapist on one hand aligns with and ratifies the client's elaboration, but on the other, also 
brings in a modification of the referential world. While the client's elaboration (lines 29-32 in Excerpt 9) depicts the missing father as a somehow childish figure who should have been whooping by the athletic field, the therapist's third position utterance shows a father who should have been an authoritative benefactor for the community (in the steering committee of the athletic club (...) supporting the youngsters work).

Through the modification of the referential world, the third position utterance underscores the fathers failed responsibility, and thereby, intensifies the sense of loss, and displays more of its ramifications: what the client is missing is not only the father cheering for his achievement, but also and perhaps primarily - the powerful and independent paternal figure. While the patient's elaboration depicted a dyadic relation (father-son), the third position utterance depicted the father in the context of the local community.

Importantly, this modification of the referential world is implicit. What the therapist says in lines 35-36 of Excerpt 9 is offered as affiliating extension of the client's description, continuing the syntactic structure in the client's response (Vehviläinen, 2003). The lack of marking any perspective shift is characteristic also for the client's next turn (see lines 38-46). While he, after a long pause, pro forma agrees with and takes up the therapist's third position utterance, he does not orient to any distinction between the 'whooping father' and the 'father in the steering committee', and thus, he does not show recognition of the modification of the psychological significance of the description. This lack of recognition is indeed in line with the implicit character of the modification: it is not in the first place offered as something to be taken up.

\section{Thematic threads in the subsequent sessions}

To further understand the therapeutic significance of the third position modifications of description like the one in excerpt 9 , we examined the sessions that took place after the ones with the focal three position sequences. It transpired that the third position modifications of the description encapsulate 
central topics that get elaborated on during the subsequent encounters. While the third position modifications of description brought just implicitly in new themes, these themes became openly attended to in the subsequent encounters. For example, in excerpt 9 above, the therapist's third position utterance invoked a broader social context: the father in the third position utterance was an active member and benefactor in the local community. Two sessions after the one Excerpt 9 was taken from, a broader social context for descriptions regarding father indeed comes up. The client tells about the time when the father was drinking heavily but had not yet left the family. Strong recollections of shame come up:

Ex. (10)

01 C: (..) tämmöstähä se oli sillo< (0.6) sillon

(..) it was like this then $(0.6)$ at the

02

\#loppuvaiheessa\# niin se- (.) tou\#hu ja

\#final stage\# that< (.) \#hassle and

03

sitte nimenomaan\#<. hhhhhh se oli tosiaan se

then in particular\#< . hhhhhh it was really it

04 oli häpeällistä.

was shameful.

$05 \quad(1.6)$ 
06 C: kyl me kärsittiin siitä helvetisti

We did suffer so goddamn badly for that

07 koko perhe. $\left({ }^{\circ} \mathrm{ku}\right.$ tota $\left.{ }^{\circ}\right)$.hhhh isa

the whole family. $\left({ }^{\circ}\right.$ as $\left.\mathrm{erm}^{\circ}\right)$.hhhh the father

08 siellä nitten (0.8)

was spending his time with these $(0.8)$

09 juoppo porukoitten mukana pyöri ja ${ }^{\circ}$ tota ${ }^{\circ}$,

drunkards and ${ }^{\circ} \mathrm{erm}^{\circ}$,

$10 \quad(3.2)$

$11 \mathrm{~T}: \mathrm{mhmm}:$.

( (8 lines omitted: some details of the

father's and his drinking buddies mishaps))

20 C: pieni kylä ni siellä niinku kaikki

tch hhh it was a small village so everybody mt hhh 
21 ties ${ }^{\circ}$ aina mitä tapahtuu: ${ }^{\circ}$.

there always knew ${ }^{\circ}$ what was happening: ${ }^{\circ}$.

$22 \quad(7.2)$

23 ?: .hhhhh hhhhhh

24 T: .hhhh (.) se on: (.) se on ihan kauhistuttava

.hhh (.) It is: (.) it is quite a horrible

25 sosiaalinen $<\mathrm{pu}^{\circ}$ toaminen $^{\circ}>$.

social $\left\langle\right.$ de $^{\circ}$ cline $\left.{ }^{\circ}\right\rangle$.

26 C: ${ }^{\circ}$ Kyllä kyllä ${ }^{\circ}$.

${ }^{\circ}$ Yes yes ${ }^{\circ}$.

$27 \quad(16.5)$

28 T: mt .hhh menestyvä mies putoaa

tch .hhh a successful man sinks 
The client's memories about his father in the context of the local community, discussed two sessions after Excerpt 9, are diametrically opposite to the depiction of the missing father in the third position utterance in Excerpt 9.Now the patient in his own initiative brings in the local community to his description of the father.

The examination of the thematic threads in the sessions that follow the one in which excerpt 9 took place suggests that the modification of the description in the third position utterance contributed in a meaningful way to the therapeutic work. It was a part of an interactional project Schegloff (2007: 244-249; Levinson, 2012) spanning over several sessions, in which the therapist and the client address a key psychological problems of the client. The third position utterance indexed a possibility for the client to consider his relation to his father from a new perspective. In a later session after the reinterpretation, the content that was first offered by the therapist appeared later in the client's own 
talk. In other words, the sequential environment where the topic was discussed moved from therapist's initiations more towards client's narration.

The development of theme that we examined here was implicit, in two ways. First, the modification of the referential world by the therapist in the third position was not flagged for the patient to attend to. The patient indeed did not display attention to the modification. Second, the return of the perspectives, initially brought in by the third position modification of description, was made in such a way that no direct connection was displayed between the third position utterance and the narratives in subsequent sessions. Unlike what shown in the preceding sections, no tying practices were employed. Rather, it appears that the participants tacitly oriented to a common cognitive ground. Such tacit orientation to joint understanding may be one way to talk about topics that are not yet clearly articulated.

\section{Discussion}

In this chapter, we examined the intertwinement of thematic threads and sequences in psychotherapy. We showed how the therapists and the clients orient themselves, explicitly and tacitly, to the longitudinal nature of the therapy, and how the topics re-emerge and get transformed while they are worked in and through sequences of talk.

While our way to analyse the data is not committed to psychotherapeutic thinking, the processes that we tracked had similarities to the processes that are of interest for psychotherapy research (e.g. Stiles, 2002). The obvious addition that CA approach can bring to understanding psychotherapeutic change processes is the sensitivity to the sequential context of the client's talk. In this chapter, we offered three different perspectives to documenting how a theme is developed in sequences. In the first one, through an analysis of the client's responses (regarding disappointment at mother), it was possible to see a robust change through standardizing the interactional context of the client's talk, i.e., by examining a sequence that recurred over time. Here, a comparison between two 
sequential contexts - reinterpretation-response sequence that was our focal sequence, and narration that preceded the suggestions - is of interest. The client did express her negative emotions towards her mother in the context of narration, but it was the position after the therapist's reinterpretation that was critical. The client can thus be seen to speak differently about her experience, in different sequential positions, even during the same period of time (Voutilainen, Peräkylä and Ruusuvuori, 2011).

In the analysis of the sequences preceding the focal interpretation in systemic therapy, we saw that the central topic appeared first in other sequential contexts (questions and formulations) in other sessions, before the more prominent reinterpretation, where the therapist directly suggested that the client's experience contains something that the client did not express as such (Bercelli, Rossano and Viaro, 2013; Peräkylä, 2012). Finally, in the analysis of the development of the theme after the focal interpretation in psychoanalysis (third empirical section above), it was shown that the modification of the theme continued through the therapist's third position utterance and later in the client's narration.

Future CA could also investigate sequential contexts of multiple themes in the same therapies. This would give a more profound picture of the therapeutic process by showing how different themes relate to each other. We also assume that therapeutic change is often non-linear and contingent in nature. Sequential CA analysis can also specify the non-continuities in the process.

Psychotherapeutic interactions are longitudinal in nature. There is historicity in the thematic threads (Schegloff, 2007) while they are worked with in single sequences. In this chapter, we have shown that the participants can orient to this historicity in different, explicit or tacit ways. What happens between a client and a therapist in a particular moment in time connects to the shared referential world that has been constructed in their earlier encounters. Thus, studying the longitudinal development of the content of the talk is as important as structural sequential analysis in order to understand the interactional meaning of any local action in psychotherapy. 


\section{References}

Bercelli, F., Rossano, F. \& Viaro, M., 2008. Clients' responses to therapists' re-interpretations. In A. Peräkylä, C. Antaki, S. Vehviläinen, and I. Leudar, eds., Conversation Analysis and Psychotherapy, pp. 43-62. Cambridge: Cambridge University Press.

Bercelli, F., Rossano, F. \& Viaro, M., 2013. Supra-session courses of action in psychotherapy. Journal of Pragmatics, 57, p. 118-37.

Fonagy, P., Gergely, G., Jurist, E., Target, M, 2002. Affect Regulation, Mentalization and the Development of the Self. New York: Other Press.

Honos-Webb, L., \& Stiles, W. B. 1998. Reformulation of assimilation analysis in terms of voices. Psychotherapy, 35, p. 23-33.

Honos-Webb, L., Surko, M., Stiles, W.B., \& Greenberg, L. S. 1999. Assimilation of voices in psychotherapy: The case of Jan. Journal of Counseling Psychology, 46, pp. 448-460.

Levinson, S. C., 2012. Action formation and ascription. In T. Stivers, \& J. Sidnell, eds. The handbook of conversation analysis, pp. 103-130. Malden, MA: Wiley-Blackwell

MacMartin, C., 2008. Resisting optimistic questions in narrative and solution-focused therapies. In A. Perakyla, C. Antaki, S. Vehvilainen \& I. Leudar (Eds.), Conversation analysis and psychotherapy, pp. 80-99. Cambridge: Cambridge University Press.

Martin, C., 2004. From other to self. Learning as interactional change. Uppsala: Acta Universitatis Upsaliensis. 
Melander, H., \& Sahlström, F., 2009. In tow of the blue whale. Learning as interactional changes in topical orientation. Journal of Pragmatics, 41, 1519-1537.

Mondada, L., 1998. Therapy interactions: Specificgenreor “'blown up" version ofordinaryconversationalpractices. Pragmatics, 8(2), pp. 155-165.

Mondada, L., \& Pekarek Doehler, S., 2004. Second language acquisition as situated practice: Task accomplishment in the French second language classroom. The Modern Language Journal, 88(4), pp. $501-518$

Muntigl, P., 2013. Resistance in couples counselling: sequences of talk that disrupt progressivity and promote disaffiliation. Journal of Pragmatics 49, pp. 18-37.

Norcross, J.C. \& Goldried, M.R., eds, 2005. Handbook of Psychotherapy Integration. New York: Oxford University Press

Stiles, W.B., 2002. Assimilation of problematic experiences. In J.C. Norcross (ed.) Psychotherapy relationships that work: Therapist contributions and responsiveness to patients, pp. 357-365. New York: Oxford University Press.

Stiles, W.B., Elliott, R., Llewelyn, S.P., FirthCozens, J.A., Margison, F.R., Shapiro, D.A., \& Hardy, G., 1990. Assimilation of problematic experiences by clients in psychotherapy. Psychotherapy, 27, pp. $411-420$.

Peräkylä, A., 2004. "Making links in psychoanalytic interpretations: a conversation analytic view". Psychotherapy Research 14, pp. 289-307.

Peräkylä, A., 2005. Patients’ responses to interpretations. A dialogue between conversation analysis and psychoanalytic theory. Communication \& Medicine 2, pp. 163-176. 
Peräkylä, A., 2011. After interpretation: Third position utterances in psychoanalysis. Research on Language and Social Interaction 44(3). pp. 288-316.

Peräkylä, A., 2012. “Die Interaktionsgeschichte einer Deutung.” In R. Ayass and C. Meyer eds.Sozialität in Slow Motion: Theoretische und empirische Perspektiven, pp. 375-405. Wiesbaden: Springer-Verlag.

Pomerantz, A. 1986. Extreme case formulations: a way of legitimizing claims. Human Studies 9 (23), 219-229

Sacks, H., 1992. Lectures on Conversation, 2 vols. Blackwell, Oxford.

Schegloff, Emanuel A., 2007. Sequence Organization in Interaction: A Primer in Conversation Analysis. Cambridge University Press, Cambridge.

Vehviläinen, S., 2003. Preparing and delivering interpretations in psychoanalytic interaction. Text 23 (4), pp. 573-606.

Viaro, M., \& Leonardi, P., 1983. Getting and giving information: analysis of a family interview strategy. Family Process 22 (1), pp. 27-42.

Voutilainen, L., Peräkylä, A., Ruusuvuori, J., 2011. Therapeutic change in interaction: conversation analysis of a transforming sequence. Psychotherapy Research 21 (3), pp. 348-365.

Voutilainen, L. \& Peräkylä, A., 2014 Therapeutic Conversation. In Östman J-O. \& Verschueren, J., eds. Handbook of Pragmatics: 2014 Installment, John Benjamins. 
Vygotsky, L., 1978. Mind in Society: The development of higher psychological processes. Cambridge, MA: Harvard University Press. 